\title{
Hydrogen Reduction of Hematite Ore Fines to Magnetite Ore Fines at Low Temperatures
}

\author{
Wenguang Du, ${ }^{1}$ Song Yang, ${ }^{1}$ Feng Pan, ${ }^{1}$ Ju Shangguan, ${ }^{1}$ Jie Lu, ${ }^{2}$ \\ Shoujun Liu, ${ }^{2}$ and Huiling Fan ${ }^{1}$ \\ ${ }^{1}$ Key Laboratory for Coal Science and Technology of Ministry of Education and Shanxi Province, \\ Institute for Chemical Engineering of Coal, Taiyuan University of Technology, Taiyuan 030024, China \\ ${ }^{2}$ College of Chemistry and Chemical Engineering, Taiyuan University of Technology, Taiyuan 030024, China
}

Correspondence should be addressed to Ju Shangguan; shanggj62@163.com

Received 6 December 2016; Revised 30 January 2017; Accepted 8 February 2017; Published 5 March 2017

Academic Editor: Maria F. Carvalho

Copyright (C) 2017 Wenguang Du et al. This is an open access article distributed under the Creative Commons Attribution License, which permits unrestricted use, distribution, and reproduction in any medium, provided the original work is properly cited.

\begin{abstract}
Surplus coke oven gases (COGs) and low grade hematite ores are abundant in Shanxi, China. Our group proposes a new process that could simultaneously enrich $\mathrm{CH}_{4}$ from COG and produce separated magnetite from low grade hematite. In this work, lowtemperature hydrogen reduction of hematite ore fines was performed in a fixed-bed reactor with a stirring apparatus, and a laboratory Davis magnetic tube was used for the magnetic separation of the resulting magnetite ore fines. The properties of the raw hematite ore, reduced products, and magnetic concentrate were analyzed and characterized by a chemical analysis method, X-ray diffraction, optical microscopy, and scanning electron microscopy. The experimental results indicated that, at temperatures lower than $400^{\circ} \mathrm{C}$, the rate of reduction of the hematite ore fines was controlled by the interfacial reaction on the core surface. However, at temperatures higher than $450^{\circ} \mathrm{C}$, the reaction was controlled by product layer diffusion. With increasing reduction temperature, the average utilization of hydrogen initially increased and tended to a constant value thereafter. The conversion of $\mathrm{Fe}_{2} \mathrm{O}_{3}$ in the hematite ore played an important role in the total iron recovery and grade of the concentrate. The grade of the concentrate decreased, whereas the total iron recovery increased with the increasing $\mathrm{Fe}_{2} \mathrm{O}_{3}$ conversion.
\end{abstract}

\section{Introduction}

Shanxi, a large coal and coke producing province in China, has a large amount of surplus coke oven gases (COGs) [1-6], which contain substantial amounts of $\mathrm{H}_{2}, \mathrm{CH}_{4}$, and $\mathrm{CO}$. In 2014, the coke output of Shanxi was 87.22 million tons, which accounted for $18.29 \%$ of the national output. If 1 t of coke can produce $430 \mathrm{Nm}^{3}$ of coke oven gas, of which approximately $200 \mathrm{Nm}^{3}$ is returned to a coke oven as a coking heat source, approximately 16 18 billion $\mathrm{Nm}^{3}$ of COGs is produced just in Shanxi. Meanwhile, the apparent consumption of natural gas in China was 178.6 billion $\mathrm{Nm}^{3}$ in 2014, which imports 63 billion $\mathrm{Nm}^{3}$ of natural gas (approximately $33.9 \%$ external dependency). $\mathrm{COG}$ methanation for $\mathrm{CH}_{4}$ enrichment can be regarded as a simple and highly efficient way of producing gas, which has attracted many specialists and scholars to research and develop the process. However, the catalysts, which are required for both the reactivity and selectivity, are sensitive to sulfide and very expensive. Can we economically obtain enriched natural gas from surplus COGs?

Due to their natural abundance, low cost, and usefulness for a variety of applications, iron ores are considered some of the most promising and important resources for the future $[7,8]$. The rapid development of the steel industry has resulted in the reduction of iron ore resources in recent years; these ores have been increasingly explored and utilized. At the same time, processed iron ores may be utilized as raw materials for the desulfurization sorbents used in gas purification; iron oxide is the main component of a renewable desulfurization sorbent for high-temperature coal gas desulfurization [912]. In addition, this new route uses iron ore as an oxygen carrier, which transfers oxygen from the combustion air to 
the fuel. Direct contact between the fuel and combustion air is prevented through the use of chemical looping combustion (CLC) [13-15].

However, using the iron ores is quite difficult due to their complex structure and nonuniform crystal size. A combination of low-temperature reduction roasting and low-intensity magnetic separation is considered a promising approach for increasing the usability of these ores [16, 17]. Lowtemperature reduction roasting can convert the weakly magnetic iron minerals $\left(\mathrm{Fe}_{2} \mathrm{O}_{3}, \mathrm{FeCO}_{3}\right.$, and $\left.\mathrm{FeS}\right)$ into a strongly magnetic phase $\left(\mathrm{Fe}_{3} \mathrm{O}_{4}\right)$, which can be easily separated by a low-intensity magnetic field. In addition, magnetization, which can be readily performed at low operating costs, is used to reduce the hematite $\left(\mathrm{Fe}_{2} \mathrm{O}_{3}\right)$ to magnetite $\left(\mathrm{Fe}_{3} \mathrm{O}_{4}\right) . \mathrm{H}_{2}, \mathrm{CO}$, $\mathrm{CH}_{4}$, and coal can be used as reducing agents $[18,19]$, and the corresponding reduction reactions should proceed as follows:

$$
\begin{gathered}
3 \mathrm{Fe}_{2} \mathrm{O}_{3}+\mathrm{H}_{2} \longrightarrow 2 \mathrm{Fe}_{3} \mathrm{O}_{4}+\mathrm{H}_{2} \mathrm{O} \\
3 \mathrm{Fe}_{2} \mathrm{O}_{3}+\mathrm{CO} \longrightarrow 2 \mathrm{Fe}_{3} \mathrm{O}_{4}+\mathrm{CO}_{2} \\
6 \mathrm{Fe}_{2} \mathrm{O}_{3}+\mathrm{C} \longrightarrow 4 \mathrm{Fe}_{3} \mathrm{O}_{4}+\mathrm{CO}_{2}
\end{gathered}
$$

Compared to coal-based reduction, gas-based reduction can be performed at lower reduction temperatures [20] and typically results in higher quality concentrates, which have lower levels of carbon deposits. $\mathrm{H}_{2}, \mathrm{CO}$, and $\mathrm{CH}_{4}$ are usually used as reducing agents in these gas-based reductions [2123].

As such, our research group has proposed an innovative process, which combines low-temperature reduction magnetization of intractable hematite with the production of substitute natural gases (SNGs) from COGs. This combined process was used to remove $\mathrm{H}_{2}, \mathrm{CO}$, and $\mathrm{H}_{2} \mathrm{~S}$, thereby enriching the methane gas contained in the COG and converting hematite to easily separated magnetite. The ultimate aim of this work was to use low grade hematite ore and the surplus COG comprehensively to obtain enriched SNG and high grade magnetite economically. Meanwhile, the whole process is described in Figure 1.

This paper, as a preliminary study of the innovative process, mainly describes the process of low-temperature hydrogen reduction of hematite ore and magnetic separation of the resulting magnetite ore, since hydrogen, which is the main component of COG, is an efficient reducing agent. The effect of this reduction on the properties of the magnetite ore is discussed.

\section{Materials and Methods}

2.1. Materials. The raw hematite ore used in this work was obtained from Guangling County, Shanxi province, China. Guangling County is located northeast of the Shanxi province. Guangling hematite ore is a Shanxi-type hematite ore.

2.2. Analysis and Characterization Method. The chemical compositions of the raw hematite ore, reduced ore samples, and concentrate ore samples were analyzed according to the

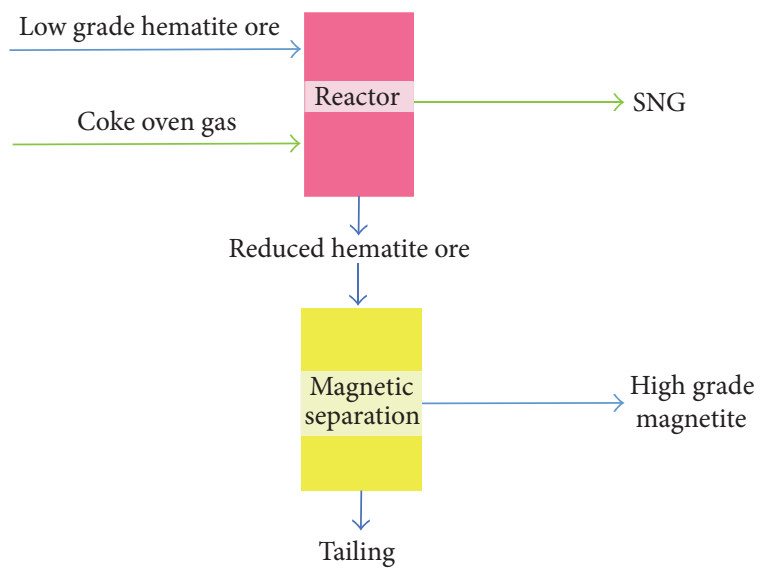

FIGURE 1: The schematic diagram of use for the low grade hematite ore and the surplus coke oven gas to produce SNGs and high grade magnetite.

National Standards of China number GB 6730.5-2008 and number GB 6730.8-2008.

The crystalline phases of the aforementioned samples were determined via X-ray diffraction (XRD) (using $\mathrm{Cu}-\mathrm{K} \alpha$ radiation, scanning rate of $8^{\circ} / \mathrm{min}$, and sweeping range of $5^{\circ}-$ $85^{\circ}$ ).

The structural characteristics of the raw hematite ore were examined using an optical microscope and a scanning electron microscope (SEM).

2.3. Experimental Procedure. A total of $100 \mathrm{~kg}$ of the raw hematite ore sample was first crushed using a jaw crusher and then sieved to a size of $2 \mathrm{~mm}$ in our laboratory. One kilogram of each of the 12 samples of the crushed hematite ore was then reduced to magnetite ore, under a total volumetric gas rate of $120 \mathrm{~L} / \mathrm{h}$, using a gas mixture of $50 \% \mathrm{H}_{2}-50 \% \mathrm{~N}_{2}$. The reduction process was performed in a fixed-bed reactor, and a stirring apparatus was used to enable full contact between the solids and the gas. The samples were reduced for 1, 1.5, 2, and $2.5 \mathrm{~h}$, at $400^{\circ} \mathrm{C}$. Similarly, the samples were reduced for $0.5,1,1.5$, and $2 \mathrm{~h}$ at both $450^{\circ} \mathrm{C}$ and $500^{\circ} \mathrm{C}$.

The total Fe content (TFe) and $\mathrm{Fe}^{2+}$ content (TFeO) of each sample were determined using a chemical analysis method. The titanium trichloride-potassium dichromate titration method was used to determine the TFe of each sample; the ferric chloride-potassium dichromate titration method was used to determine the $\mathrm{TFeO} . \mathrm{Fe}_{3} \mathrm{O}_{4}$ contains one $\mathrm{Fe}^{2+}$ and two $\mathrm{Fe}^{3+}$ ions. Therefore, if all the hematite in the raw ore sample is reduced to $\mathrm{Fe}_{3} \mathrm{O}_{4}$, then the TFe and TFeO of the reduced sample are related through by $\mathrm{TFeO}=3 / 7 \mathrm{TFe}$. The conversion of $\mathrm{Fe}_{2} \mathrm{O}_{3}\left(X_{\mathrm{Fe}_{2} \mathrm{O}_{3}}\right)$ to $\mathrm{Fe}_{3} \mathrm{O}_{4}$ in each reduced sample can then be calculated by determining the TFe and $\mathrm{TFeO}$ of each reduced sample. $X_{\mathrm{Fe}_{2} \mathrm{O}_{3}}$ was calculated from

$$
X_{\mathrm{Fe}_{2} \mathrm{O}_{3}} \%=\frac{7 W_{\mathrm{TFeO}}}{3 W_{\mathrm{TFe}}} \times 100 \%
$$


The grain sizes of the newly generated magnetite were calculated from

$$
D=\frac{R l}{\beta \cos q},
$$

where $D$ is the distance between the atomic layers in the crystals, $R$ is Scherer's constant, $l$ is the wavelength of the $\mathrm{X}$ ray radiation, $q$ is the diffraction angle, and $\beta$ is the full width at half maximum.

As for the low-intensity magnetic separation of the reduced samples, the optimal grinding fineness and magnetic field intensity should be chosen such that the optimal magnetic separation index is obtained. In this paper, reduced samples with different degrees of grinding fineness and magnetic field intensities were obtained by varying the grinding time and the working electrical current of the Davis tube magnetic separator, respectively. The experiments aimed at optimizing the grinding fineness and magnetic field intensity were performed for samples reduced at $500^{\circ} \mathrm{C}$ for $0.5 \mathrm{~h}$ or $2.0 \mathrm{~h}$. The reduced samples were dry milled in a rod mill for various times and then separated by a laboratory Davis tube magnetic separator, with a working electrical current of $2 \mathrm{~A}$, in order to determine the best grinding fineness. Furthermore, in order to determine the optimum magnetic field intensity, reduced samples with the best grinding fineness were separated by a laboratory Davis tube magnetic separator operating at various electrical currents.

Each of the 12 reduced samples was dry milled in a rod mill for $15 \mathrm{~min}$ and then separated by a laboratory Davis tube magnetic separator (model: XCGS $\varphi 50$ ), operating at a working electrical current of $2 \mathrm{~A}$ (magnetic field intensity: $0.156 \mathrm{~T}$ ). The grades and weights of the magnetic concentrates were determined, and the recovery of iron $\left(R_{\mathrm{Fe}}\right)$, which is the index of magnetic separation, was calculated during the low-intensity magnetic separation; $R_{\mathrm{Fe}}$, the amount of iron recovered in the final concentrate, was calculated from

$$
R_{\mathrm{Fe}}=\frac{m_{1} \times T_{\mathrm{Fe} 1}}{m_{2} \times T_{\mathrm{Fe} 2}} \times 100 \%,
$$

where $R_{\mathrm{Fe}}, m_{1}, T_{\mathrm{Fe} 1}, m_{2}$, and $T_{\mathrm{Fe} 2}$ are the amount of iron recovered during the low-intensity magnetic separation, quality of the concentrate, iron content of the concentrate, quality of the reduced samples, and iron content of the reduced samples, respectively.

\section{Results and Discussions}

3.1. Properties of the Raw Ore Samples. The mineral composition, main chemical composition, and iron distribution of the raw hematite samples are listed in Tables 1, 2, and 3, respectively; the crystalline phase is shown in Figure 2.

The Guangling hematite ore sample consisted of $58.83 \%$ $\mathrm{Fe}_{2} \mathrm{O}_{3}, 19.53 \% \mathrm{SiO}_{2}, 6.75 \% \mathrm{Al}_{2} \mathrm{O}_{3}, 0.21 \% \mathrm{FeO}, 2.46 \% \mathrm{CaO}$, $1.38 \% \mathrm{MgO}, 0.11 \% \mathrm{Na}_{2} \mathrm{O}$, and $3.65 \% \mathrm{~K}_{2} \mathrm{O}$. Harmful elements, such as phosphorus and sulfur, were present in only low quantities. This hematite ore contained a small amount of magnetite; hematite is the precious form of iron minerals. The gangue minerals were composed mainly of quartz and
TABLE 1: Mineral composition of the hematite ore.

\begin{tabular}{lc}
\hline Components & Content (wt.\%) \\
\hline Hematite & 53 \\
Limonite & 4 \\
Quartz & 20 \\
Mica & 5 \\
Kaolinite & 8 \\
Barite & Trace \\
\hline
\end{tabular}

TABLE 2: Chemical composition of the hematite ore.

\begin{tabular}{lc}
\hline Components & Content (wt.\%) \\
\hline $\mathrm{TFe}$ & 41.14 \\
$\mathrm{Fe}_{2} \mathrm{O}_{3}$ & 58.83 \\
$\mathrm{FeO}$ & 0.21 \\
$\mathrm{SiO}_{2}$ & 19.53 \\
$\mathrm{CaO}$ & 2.46 \\
$\mathrm{Al}_{2} \mathrm{O}_{3}$ & 6.75 \\
$\mathrm{MgO}_{\mathrm{Na}}$ & 1.38 \\
$\mathrm{Na}_{2} \mathrm{O}$ & 0.11 \\
$\mathrm{~K}_{2} \mathrm{O}$ & 3.65 \\
$\mathrm{~S}$ & 0.18 \\
$\mathrm{P}$ & 0.66 \\
$\mathrm{LOI}$ & 3.95 \\
\hline
\end{tabular}

${ }^{*}$ LOI: loss on ignition.

TABLE 3: Iron distribution of the hematite ore.

\begin{tabular}{lcc}
\hline Components & Content (wt.\%) & Fraction (wt.\%) \\
\hline Magnetic iron & 0.057 & 0.14 \\
Siderite & 0.057 & 0.14 \\
Iron sulfide & 0.057 & 0.14 \\
Iron silicate & 0.50 & 1.21 \\
Hematite and limonite & 40.4 & 98.37 \\
TFe & 41.07 & 100 \\
\hline
\end{tabular}

small amounts of mica and kaolinite. Furthermore, there was a 3.95\% loss upon ignition for the Guangling hematite ore. As Figure 2 shows, the Guangling hematite ore was composed mainly of hematite and the nonmetallic mineral, quartz.

The optical micrographs in Figure 3 reveal that the Guangling hematite ore mainly had taxitic structure, disseminated structure, and similar oolitic structure; the hematite mixed with quartz or mica, hematite, quartz, and clay (mainly kaolinite) formed an oolitic-like structure, quartz formed the core of the similar oolitic structure, and hematite and clay (mainly kaolinite) formed a concentric circle in the similar oolitic structure.

The corresponding SEM images (Figure 4) confirmed that the hematite ore consisted mainly of scaly, acicular, cryptocrystalline, and metasomatic textures, with a sand consolidation structure (rarely, with an oolitic structure). The acicular and scaly hematite ores are bright white, whereas quartz shows a grey color. The disseminated structure of the hematite was very fine. 


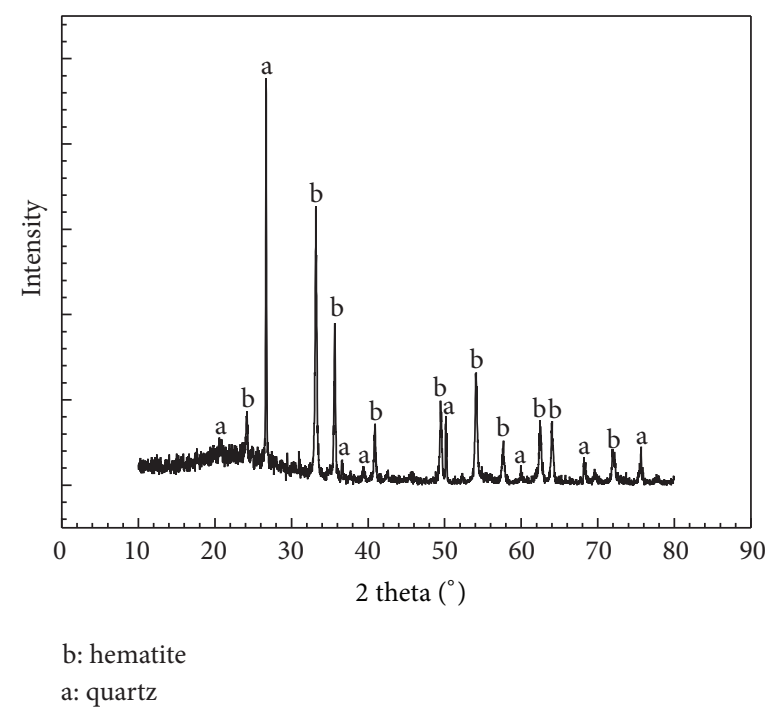

FIGURE 2: XRD pattern of the raw hematite ore.

Therefore, the hematite ore used in this study was a typical complex, fine-grained, marine-sediment-refractory hematite ore.

\subsection{Reducing Magnetization of the Raw Hematite Ore}

3.2.1. Thermodynamics of Reducing $\mathrm{Fe}_{2} \mathrm{O}_{3}$ with $\mathrm{H}_{2}$. The Gibbs free energy function method was adopted for the thermodynamic calculation of the $\mathrm{H}_{2}$-reduction of $\mathrm{Fe}_{2} \mathrm{O}_{3}[24,25]$; the results are shown in Figure 5.

Three reduction products were formed, namely, $\mathrm{Fe}_{3} \mathrm{O}_{4}$, $\mathrm{FeO}$, and $\mathrm{Fe}$. Moreover, $\mathrm{Fe}_{2} \mathrm{O}_{3}$ reacted with $\mathrm{H}_{2}$ to form $\mathrm{Fe}_{3} \mathrm{O}_{4}$ at reduction temperatures of $400^{\circ} \mathrm{C}-600^{\circ} \mathrm{C}$ and $\mathrm{H}_{2}$ concentrations of $<65 \mathrm{vol}$. $\%$.

3.2.2. Effect of the Reduction Temperature and Time on the Conversion of $\mathrm{Fe}_{2} \mathrm{O}_{3}$. Short, low-temperature reduction processes can reduce the cost of magnetizing the hematite ore. The dependence of the $\mathrm{Fe}_{2} \mathrm{O}_{3}$ conversion in the hematite ore on the reduction time (Figure 6) was investigated at the temperatures of $400^{\circ} \mathrm{C}, 450^{\circ} \mathrm{C}$, and $500^{\circ} \mathrm{C}$.

As Figure 6 shows, at $400^{\circ} \mathrm{C}$, the amount of $\mathrm{Fe}_{2} \mathrm{O}_{3}$ converted increased linearly with the increasing reduction time. At reduction temperatures of $450^{\circ} \mathrm{C}$ or $500^{\circ} \mathrm{C}$, the amount of $\mathrm{Fe}_{2} \mathrm{O}_{3}$ converted increased rapidly at the beginning of the reaction and slowly thereafter. The shrinking unreacted core model stipulates that there is a sharp boundary between the reacted (magnetite: $\mathrm{Fe}_{3} \mathrm{O}_{4}$ ) and the unreacted (hematite: $\mathrm{Fe}_{2} \mathrm{O}_{3}$ ) parts of the particle [26]. The hematite is reduced to magnetite $\left(\mathrm{Fe}_{3} \mathrm{O}_{4}\right)$ via the diffusion of hydrogen through the product layer on the boundary (reacted-unreacted interface). As reduction proceeds, the boundary eventually recedes to the center, the hematite is exhausted, and the thickness of the product layer (magnetite layer) increases. The product layer diffusion and the interfacial reaction on the surface of the core constitute the rate-limiting steps of the process $[25,26]$.

The interfacial reaction on the surface of the core proceeded very slowly at low reduction temperatures. In fact, the rate of the interfacial reaction is significantly lower than that of the hydrogen diffusion process. Therefore, the interfacial reaction constituted the rate-limiting step of the process. Since the reduction temperature was constant and very low, the reaction proceeded extremely slowly; the conversion of $\mathrm{Fe}_{2} \mathrm{O}_{3}$ was proportional to the reduction time.

When the reduction temperature was high, the interfacial reaction on the core surface proceeded rapidly and at a significantly higher rate than that of the hydrogen diffusion process. Diffusion into the product layer was, therefore, the rate-limiting step of the process. During the beginning of reduction, the reaction proceeded rapidly since the product layer was very thin, and the diffusion resistance of hydrogen was correspondingly small. As the reduction proceeded, the thickness of the product layer increased the diffusion resistance of hydrogen, which in turn led to a sharp decrease in the reaction rate with the increasing reduction time.

The aforementioned results show that the transition of hematite $\left(\mathrm{Fe}_{2} \mathrm{O}_{3}\right)$ to magnetite $\left(\mathrm{Fe}_{3} \mathrm{O}_{4}\right)$ proceeded according to a shrinking unreacted core model. When the reduction temperature was low, the reaction rate was controlled by the interfacial reaction on the surface of the core; when the reduction temperature was high, the reaction rate was controlled by diffusion into the product layer.

On average, $\sim 18.6 \%, 23.1 \%$, and $23.4 \%$ of the hydrogen were utilized during the reduction process at $400^{\circ} \mathrm{C}, 450^{\circ} \mathrm{C}$, and $500^{\circ} \mathrm{C}$, respectively. This indicates that the average utilization of hydrogen increased initially and tended, subsequently, to a constant value with the increasing reduction temperature.

XRD was used to characterize 12 samples, which were reduced for $1 \mathrm{~h}, 1.5 \mathrm{~h}, 2 \mathrm{~h}$, and $2.5 \mathrm{~h}$, at the respective reduction temperatures of $400^{\circ} \mathrm{C}, 450^{\circ} \mathrm{C}$, and $500^{\circ} \mathrm{C}$, as shown in Figures 7, 8, and 9. As the figures show, the intensity of the peaks corresponding to hematite and magnetite decreases and increases, respectively, with the increasing reduction time. This indicates that the rate of reaction increased with 

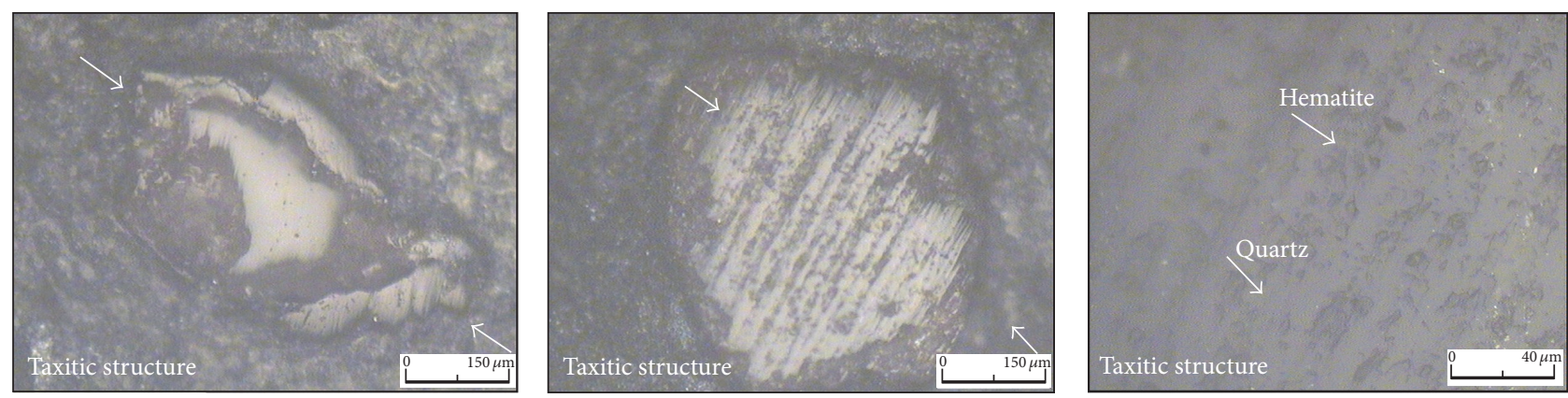

(a)
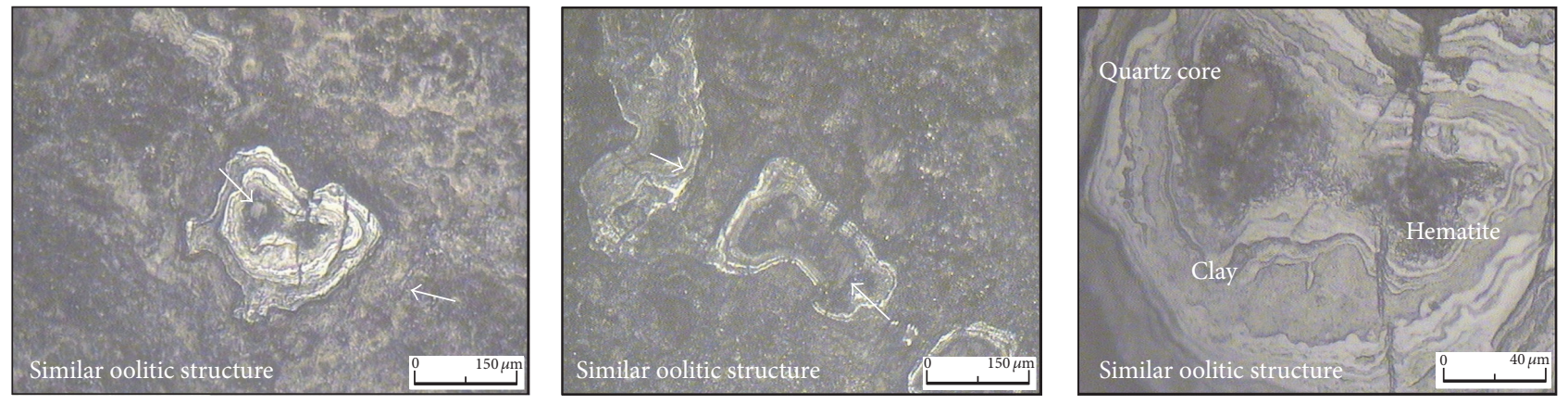

(b)
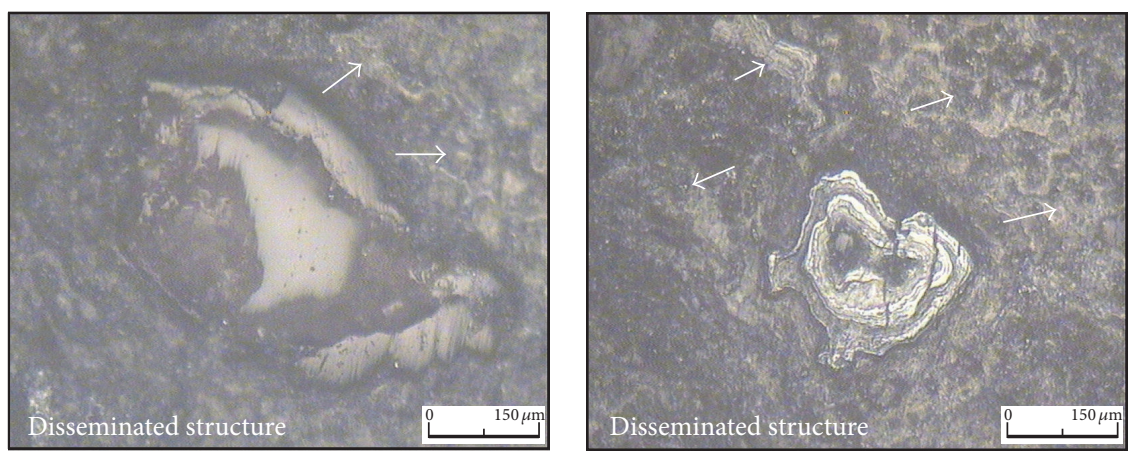

(c)

Figure 3: Optical microscope images of the raw hematite ore.

the increasing temperature. Moreover, nearly all the hematite was reduced to magnetite during the process.

3.3. Mechanism of Reduction Magnetization Process. The grain size of the newly generated magnetite is shown in Figure 9.

Figure 10 shows that the grain size of the newly generated magnetite increased initially and then decreased slightly and increased thereafter. Based on the structural characteristics of the hematite, this grain size trend also indicates that the transition of hematite $\left(\mathrm{Fe}_{2} \mathrm{O}_{3}\right)$ to magnetite $\left(\mathrm{Fe}_{3} \mathrm{O}_{4}\right)$ followed a shrinking unreacted core model [27-29]. This transition progressed in three steps [30].

Step 1. $\mathrm{H}_{2}$ molecules diffused through the air and were absorbed on the surface of hematite; these $\mathrm{H}_{2}$ molecules were then activated. These active $\mathrm{H}_{2}$ molecules combined with
$\mathrm{O}^{2-}$ from the $\mathrm{Fe}_{2} \mathrm{O}_{3}$ lattice, thereby generating $\mathrm{H}_{2} \mathrm{O}$ [31]. Moreover, the two electrons released, during the reaction, reduced $\mathrm{Fe}^{3+}$ to $\mathrm{Fe}^{2+}$ :

$$
\begin{aligned}
\mathrm{H}_{2}+\mathrm{O}^{2-} & =\mathrm{H}_{2} \mathrm{O}+2 \mathrm{e}^{-} \\
2 \mathrm{Fe}^{3+}+2 \mathrm{e}^{-} & =2 \mathrm{Fe}^{2+}
\end{aligned}
$$

Step 2. The new generation of $\mathrm{Fe}^{2+}$ combined with $\mathrm{Fe}_{2} \mathrm{O}_{3}$, thereby producing $\mathrm{Fe}_{3} \mathrm{O}_{4}$ through lattice reconstruction [31, 32]:

$$
4 \mathrm{Fe}_{2} \mathrm{O}_{3}+\mathrm{Fe}^{2+}+2 \mathrm{e}^{-}=3 \mathrm{Fe}_{3} \mathrm{O}_{4}\left(\mathrm{Fe}_{2} \mathrm{O}_{3} \cdot \mathrm{FeO}\right)
$$

Step 3. During the above process, the reduction reaction extended continuously to the inner layer, and the entire hematite particle was completely reduced to magnetite [32]. 

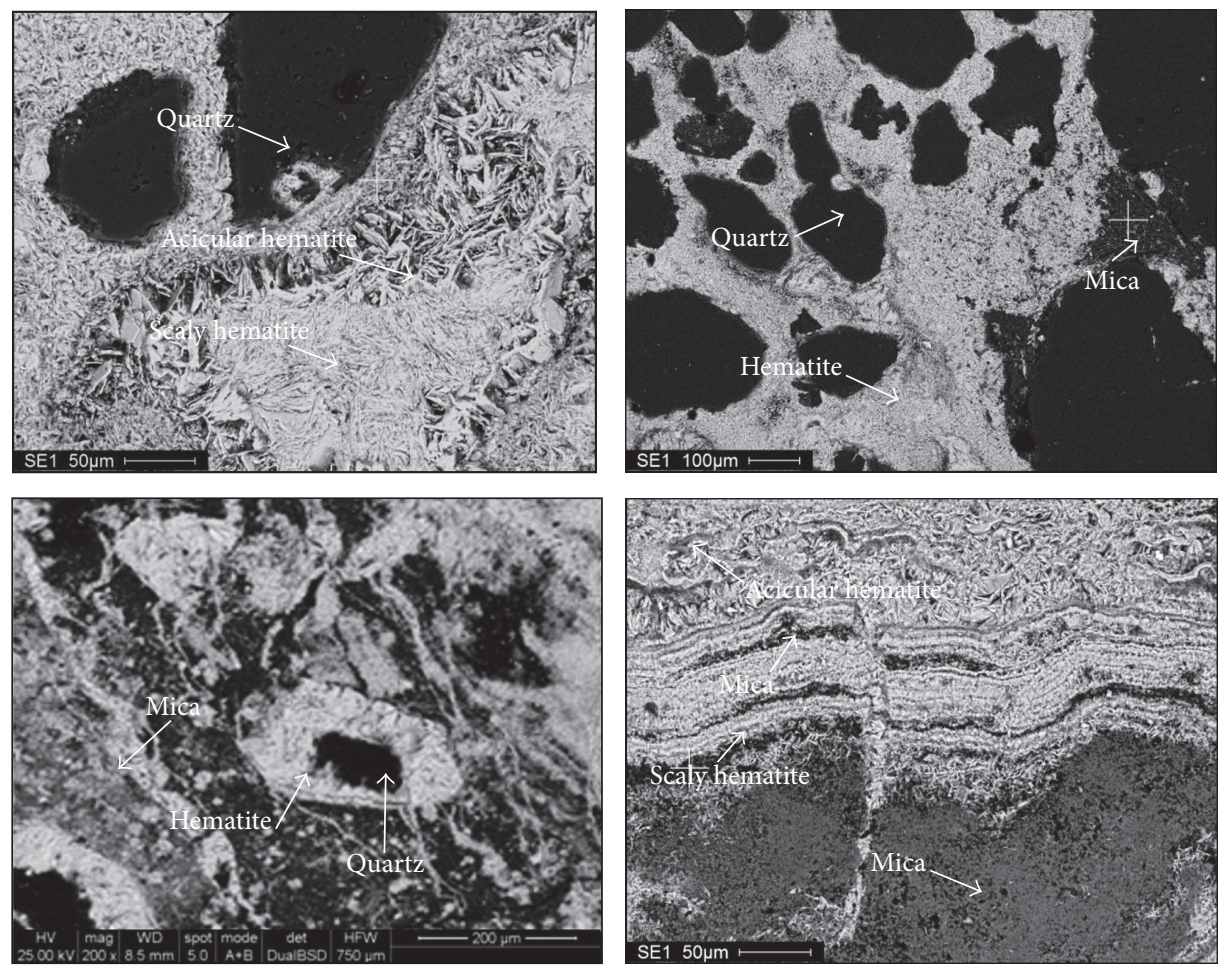

FIGURE 4: SEM images of the raw hematite ore.

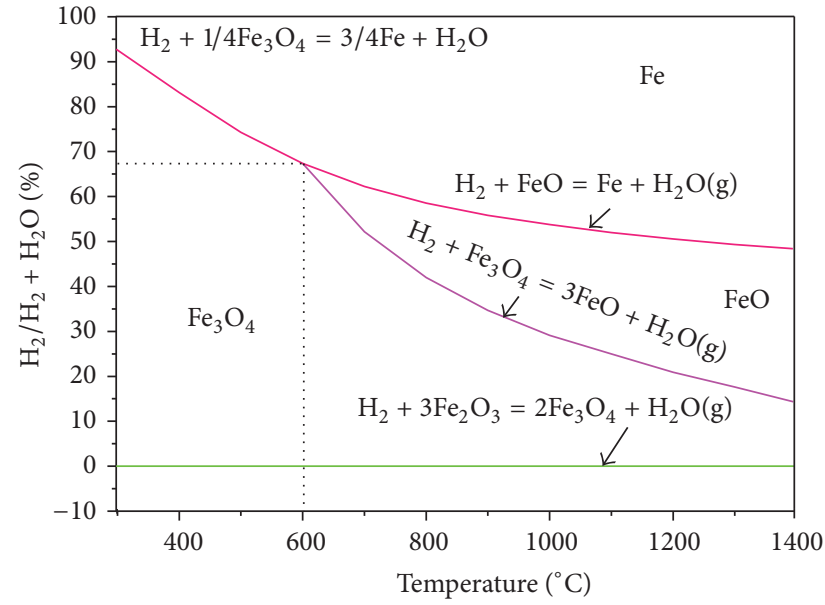

FIGURE 5: Gas-phase equilibrium composition of $\mathrm{H}_{2}$-reduced iron oxide.

Figure 11 shows the SEM images of samples reduced for $1 \mathrm{~h}$ and $2.5 \mathrm{~h}$ at $400^{\circ} \mathrm{C}$ as well as for $0.5 \mathrm{~h}$ and $2 \mathrm{~h}$ at $500^{\circ} \mathrm{C}$.

The grain sizes of the new-generation magnetite increased with the increasing reaction time. Furthermore, the amount of $\mathrm{Fe}_{2} \mathrm{O}_{3}$ converted and the number of grains generated increased with the increasing reaction temperature and time.

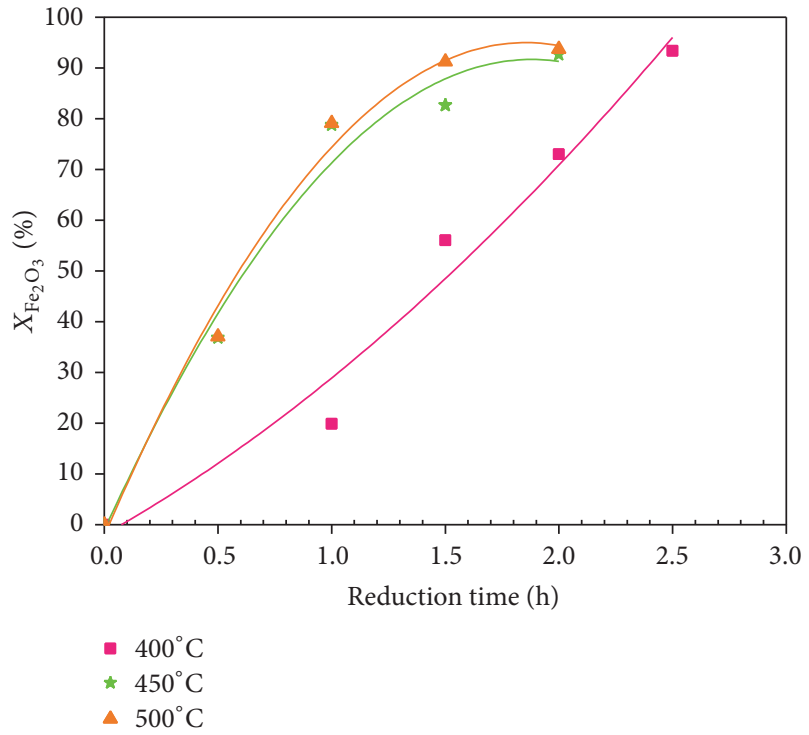

FIGURE 6: Effect of reaction time on the conversion of $\mathrm{Fe}_{2} \mathrm{O}_{3}$ at different temperatures.

\subsection{Low-Intensity Magnetic Separation of the Reduced Samples}

3.4.1. Optimization of the Grinding Fineness and Magnetic Field Intensity. To obtain a high grade concentrate with 


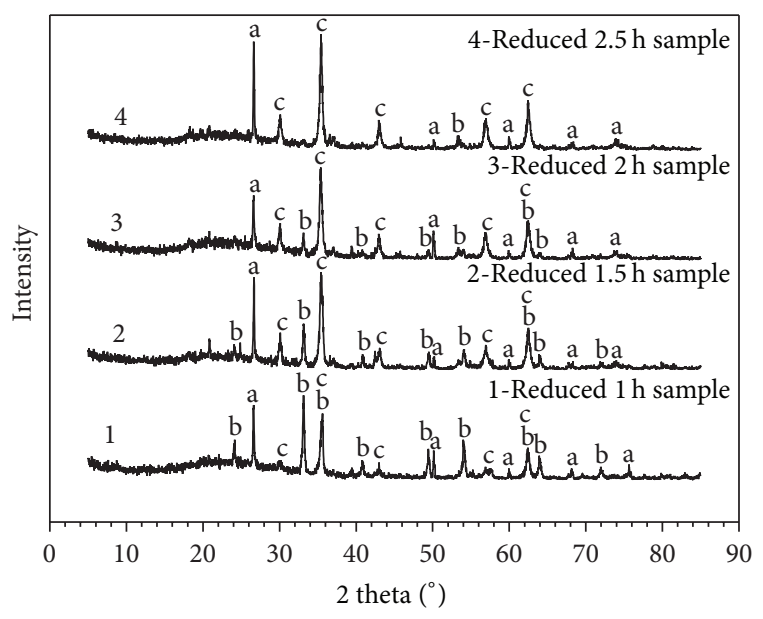

b: hematite

c: magnetite

a: quartz

FIGURE 7: XRD patterns of samples reduced at $400^{\circ} \mathrm{C}$.

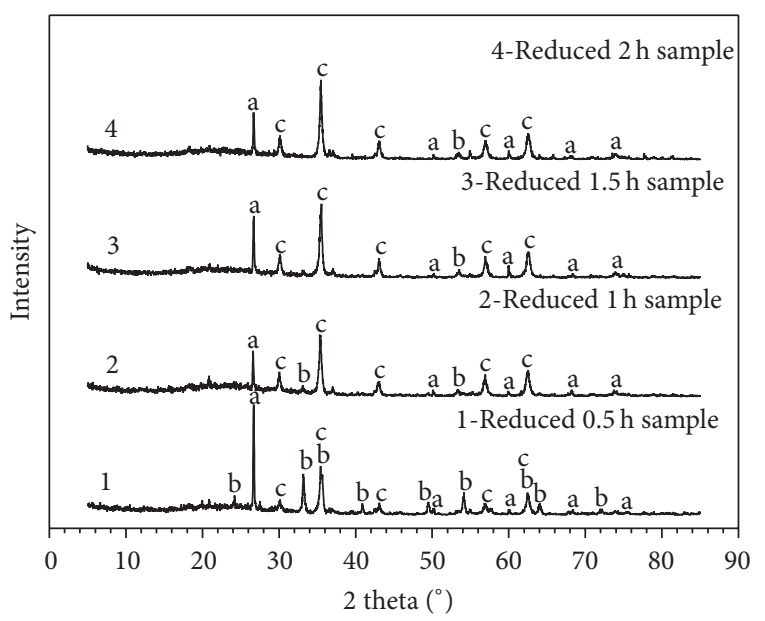

\section{b: hematite \\ c: magnetite \\ a: quartz}

FIGURE 8: XRD patterns of samples reduced at $450^{\circ} \mathrm{C}$.

excellent Fe recovery, experiments on the grinding fineness of the ore were performed prior to magnetic separation of the reduced samples. The results obtained for the samples reduced at $500^{\circ} \mathrm{C}$ for $0.5 \mathrm{~h}$ and $2.0 \mathrm{~h}$ are shown in Figures 1215.

The figures reveal an optimum grinding time of $15 \mathrm{~min}$ and a corresponding grinding fineness and iron recovery of -200 mesh and $70.78 \%$, respectively. In addition, the optimum magnetic field intensity $(0.156 \mathrm{~T})$ for magnetic separation occurred at an electrical current of $2 \mathrm{~A}$.

The grain size of the hydrogen-reduced new-generation magnetite influenced the dissociation of the core and, therefore, played an important role in the subsequent magnetic separation. Comparing Figure 9 with Figures 14 and 15 reveals that the increases in the grain size for the former and latter

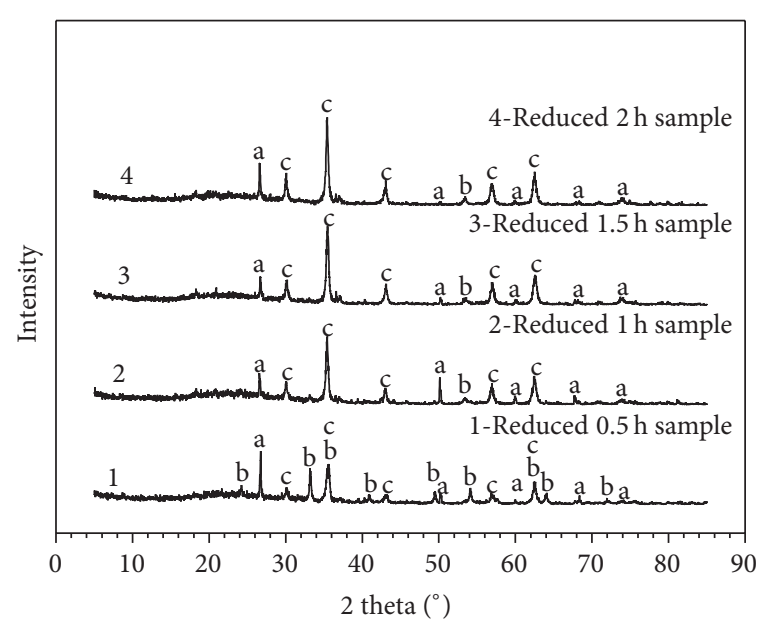

$$
\begin{aligned}
& \text { b: hematite } \\
& \text { c: magnetite } \\
& \text { a: quartz }
\end{aligned}
$$

FIGURE 9: XRD patterns of samples reduced at $500^{\circ} \mathrm{C}$.

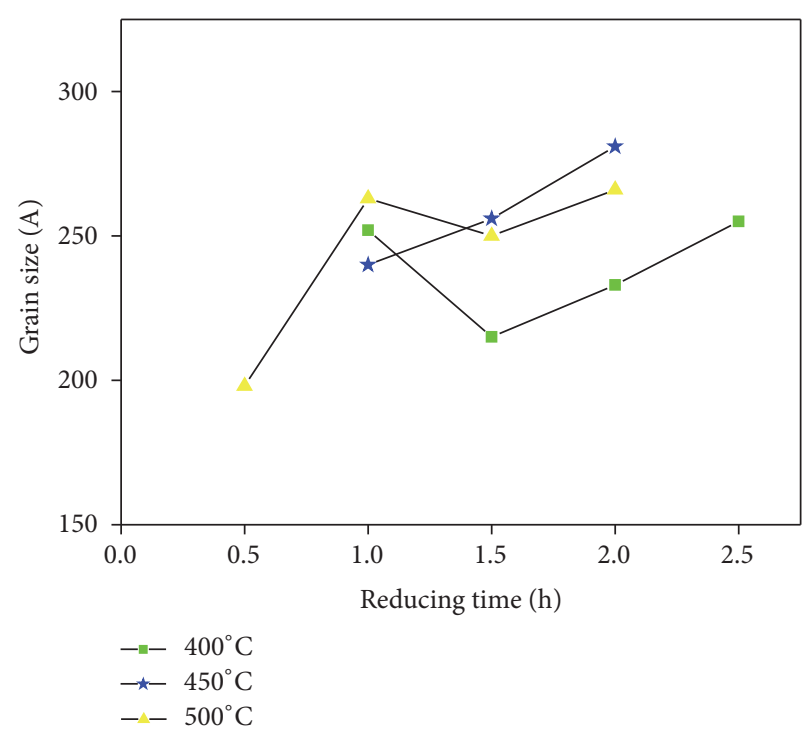

FIGURE 10: Grain size of the new-generation magnetite $\left(\mathrm{Fe}_{3} \mathrm{O}_{4}\right)$.

figures for the new-generation magnetite were favorable and unfavorable, respectively, to the dissociation of the ore.

3.4.2. Effect of Reduction on the Magnetic Separation. The relationship between the grade of the concentrate and the conversion of $\mathrm{Fe}_{2} \mathrm{O}_{3}$ (in the hematite ore) at a given reduction temperature was determined by analyzing the total iron content; the results are shown in Figure 16.

As Figure 16 shows, the grade of the concentrate decreased sharply with the increasing amount of converted $\mathrm{Fe}_{2} \mathrm{O}_{3}$. This indicates that the $\mathrm{Fe}_{2} \mathrm{O}_{3}$ conversion played an important role in determining the grade of the concentrate.

According to the shrinking unreacted core model, the reduction of hematite $\left(\mathrm{Fe}_{2} \mathrm{O}_{3}\right)$ to magnetite $\left(\mathrm{Fe}_{3} \mathrm{O}_{4}\right)$ proceeded from the outer surface to the center of the hematite 


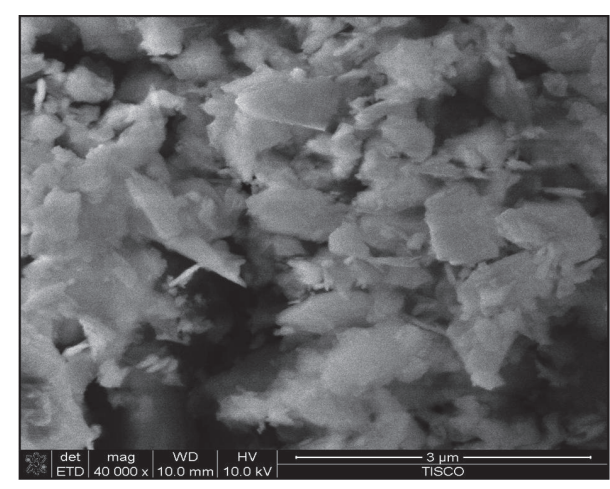

(a)

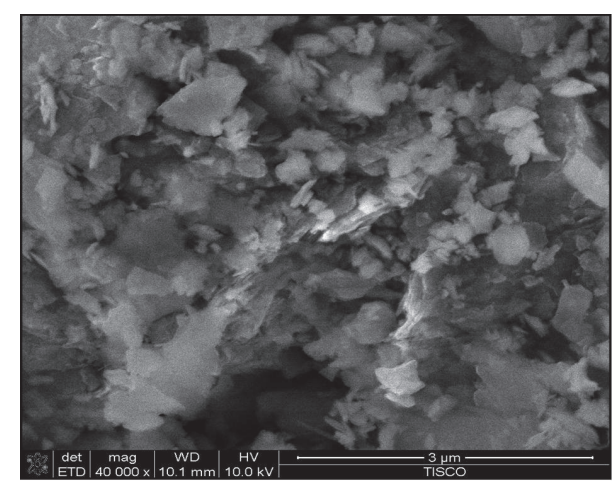

(c)

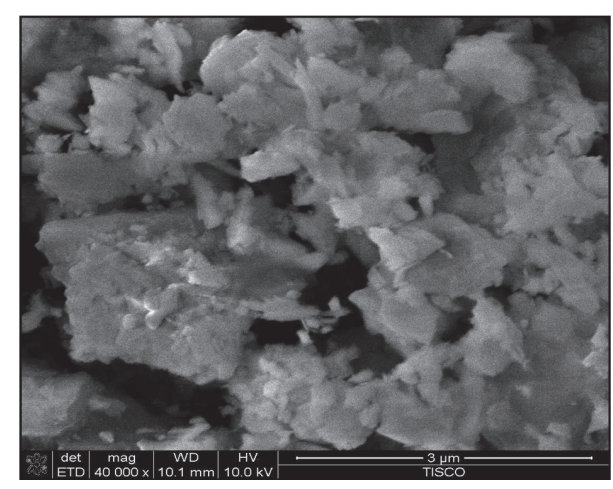

(b)

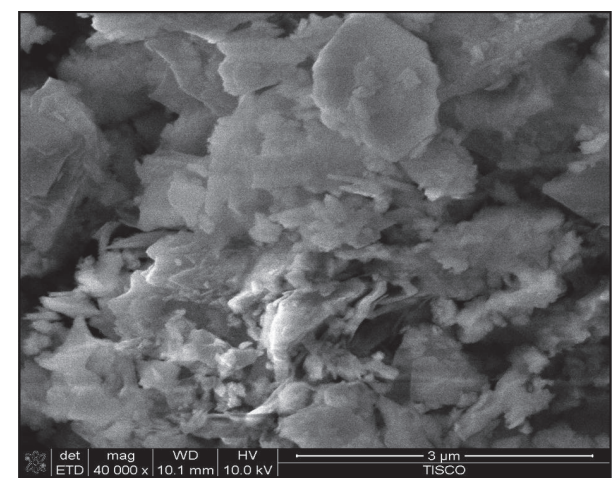

(d)

Figure 11: SEM images of samples reduced for (a) $1 \mathrm{~h}$ at $400^{\circ} \mathrm{C}$, (b) $2.5 \mathrm{~h}$ at $400^{\circ} \mathrm{C}$, (c) $0.5 \mathrm{~h}$ at $500^{\circ} \mathrm{C}$, and (d) $2 \mathrm{~h}$ at $500^{\circ} \mathrm{C}$.

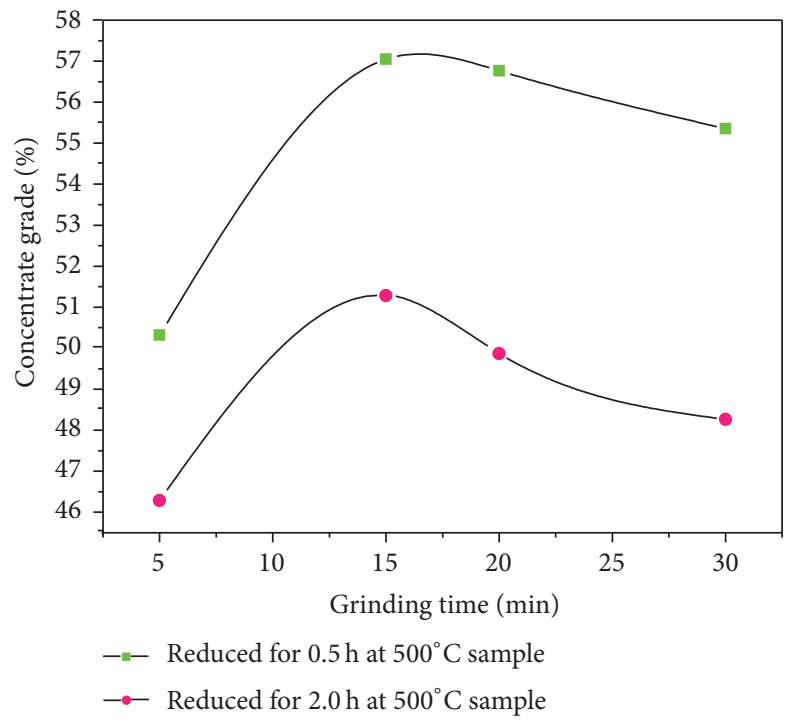

FIGURE 12: Effect of grinding time on the grade of the concentrate.

ore particle. The product layer (magnetite layer) thickened with the progression of reduction, and the unreacted gangue in the hematite ore particle was inevitably encapsulated by the new-generation magnetite $\left(\mathrm{Fe}_{3} \mathrm{O}_{4}\right)$. This enclosure hindered the dissociation of the gangue and the newly generated magnetite $\left(\mathrm{Fe}_{3} \mathrm{O}_{4}\right)$, and, as a result, the grade of the

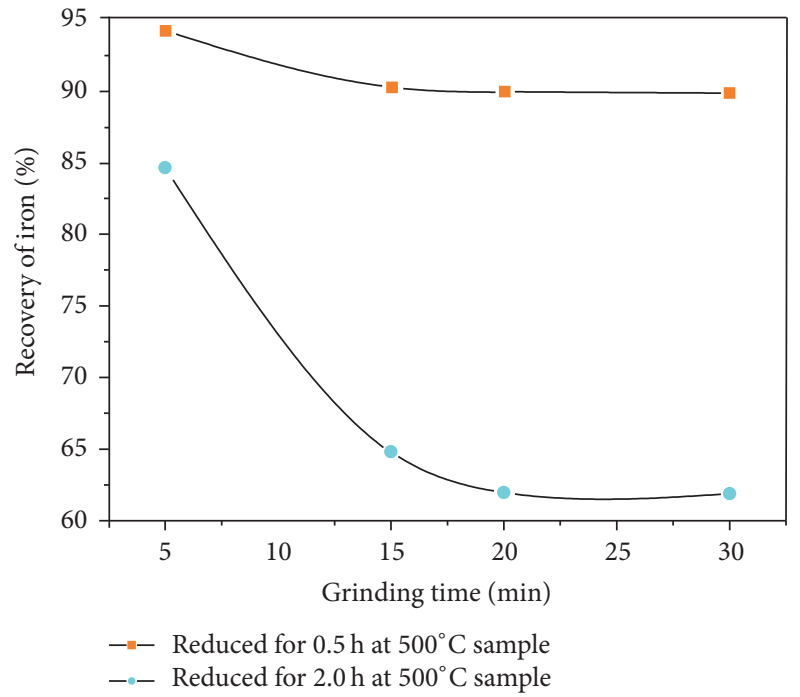

FIGURE 13: Effect of grinding time on the recovery of iron.

magnetic concentrate decreased with the increasing amount of converted $\mathrm{Fe}_{2} \mathrm{O}_{3}$.

The dependence of the iron recovery on the conversion of $\mathrm{Fe}_{2} \mathrm{O}_{3}$ at specific reduction temperatures was determined by analyzing the total iron content in both the hematite and concentrate ores; the results are shown in Figure 17. 


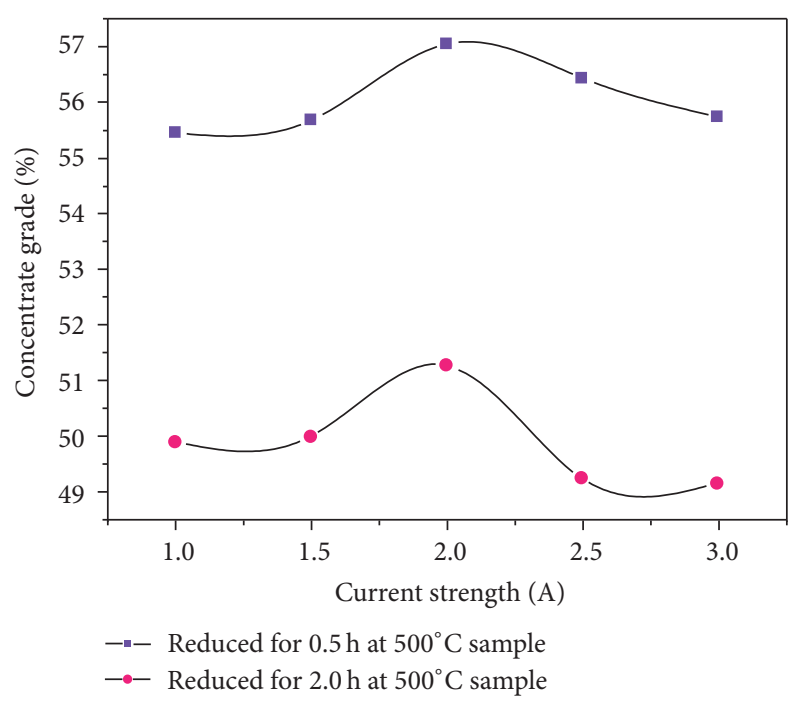

FIGURE 14: Effect of current strength on the concentrate grade.

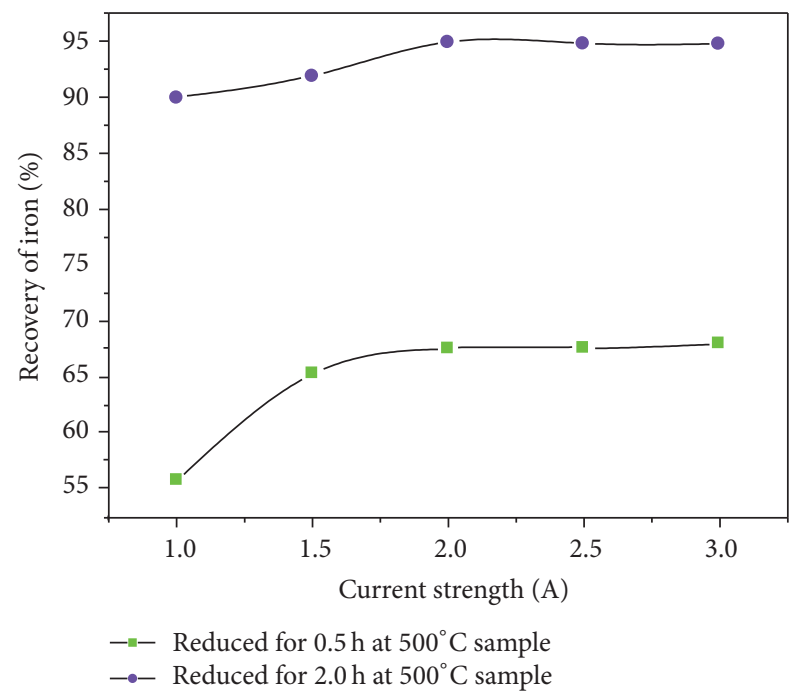

FIGURE 15: Effect of grinding time on the recovery of iron.

As Figure 17 shows, the total iron recovery increased significantly with the increasing amount of converted $\mathrm{Fe}_{2} \mathrm{O}_{3}$. This indicates that the $\mathrm{Fe}_{2} \mathrm{O}_{3}$ conversion played an important role in the recovery of iron.

The amount of hematite reduced to magnetite increased with the increasing amount of converted $\mathrm{Fe}_{2} \mathrm{O}_{3}$ and resulted, in turn, in increased total iron recovery. Therefore, the conversion of $\mathrm{Fe}_{2} \mathrm{O}_{3}$ in the hematite ore had a significant effect on the total iron recovery and concentrate grade. In fact, the concentrate grade decreased, whereas the total iron recovery increased, with the increasing $\mathrm{Fe}_{2} \mathrm{O}_{3}$ conversion.

The grade of the concentrate reduced at $450^{\circ} \mathrm{C}$ for $30 \mathrm{~min}$ and milled in a rod mill for 15 min could be improved (to grade: $56.99 \%$, iron recovery rate: $61.93 \%$ ) by performing a simple magnetic separation process, using a working electrical current of $2 \mathrm{~A}$ (magnetic field intensity: $0.156 \mathrm{~T}$ ); this process could also be used to improve the iron recovery rate of

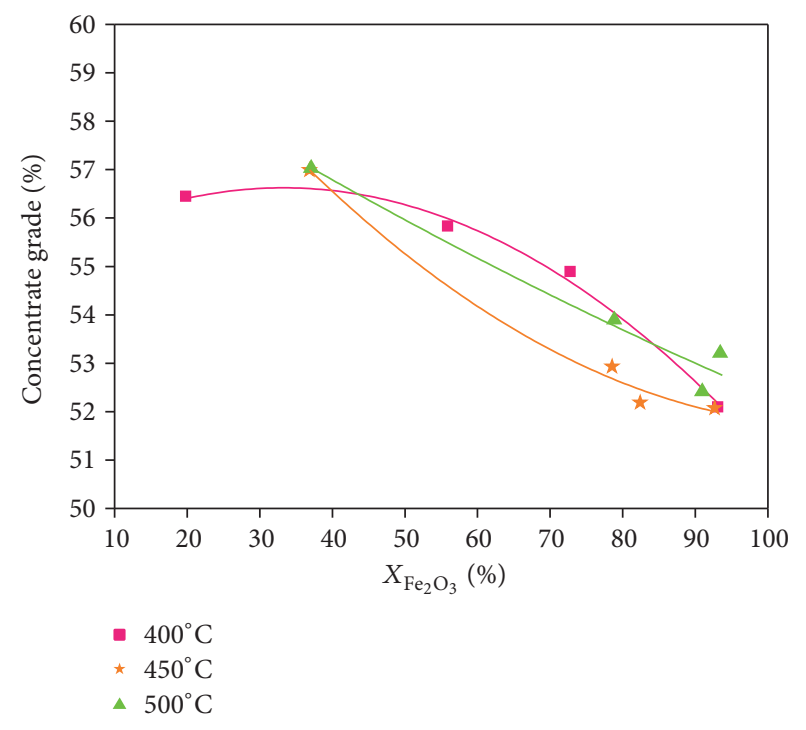

FIGURE 16: Dependence of the concentrate grade on the conversion of $\mathrm{Fe}_{2} \mathrm{O}_{3}$.

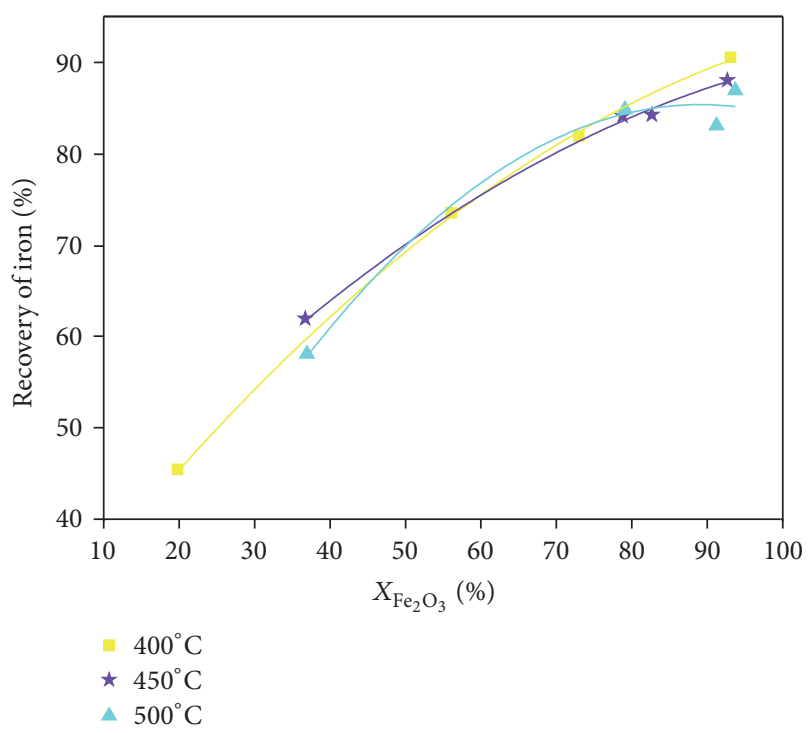

FIGURE 17: Dependence of iron recovery on the conversion of $\mathrm{Fe}_{2} \mathrm{O}_{3}$.

the concentrate (to grade: $52.06 \%$, iron recovery rate: $90.5 \%$ ), which was reduced at $400^{\circ} \mathrm{C}$ for $150 \mathrm{~min}$ and rod-milled for $15 \mathrm{~min}$.

\section{Conclusions}

We conclude the following:

(1) One kilogram of hematite $(-2 \mathrm{~mm})$ was reduced under a total volumetric gas rate of $120 \mathrm{~L} / \mathrm{h}$ (gas mixture composition: $50 \% \mathrm{H}_{2}-50 \% \mathrm{~N}_{2}$ ). At reduction temperatures lower than $400^{\circ} \mathrm{C}$, the rate of the reduction reaction of the hematite ore fines was controlled by the interfacial reaction on the core surface. However, at temperatures higher than $450^{\circ} \mathrm{C}$, 
the reaction rate was controlled by the product layer diffusion. With an increasing reduction temperature, the average utilization of hydrogen increased initially and tended to a constant value thereafter.

(2) The grade of the concentrate decreased and the total iron recovery increased with increasing $\mathrm{Fe}_{2} \mathrm{O}_{3}$ conversion. The grade of the concentrate, which was reduced at $450^{\circ} \mathrm{C}$ for $30 \mathrm{~min}$ and rod-milled for $15 \mathrm{~min}$, was improved (to grade: $56.99 \%$, iron recovery rate: $61.93 \%$ ) through a simple magnetic separation process using a working electrical current of $2 \mathrm{~A}$ (magnetic field intensity: $0.156 \mathrm{~T}$ ); this process was also used to improve the iron recovery rate (to grade: $52.06 \%$, iron recovery rate: $90.5 \%$ ) of the concentrate, which was reduced at $400^{\circ} \mathrm{C}$ for $150 \mathrm{~min}$ and rodmilled for $15 \mathrm{~min}$.

(3) During the reduction magnetization, the grain size of the new-generation magnetite increased initially and then decreases slightly and increased thereafter. The former and latter increases in the grain size were favorable and unfavorable, respectively, to the dissociation of the hematite ore. In addition, the transition of hematite $\left(\mathrm{Fe}_{2} \mathrm{O}_{3}\right)$ to magnetite $\left(\mathrm{Fe}_{3} \mathrm{O}_{4}\right)$ followed a shrinking unreacted core model.

\section{Competing Interests}

The authors declare that they have no conflict of interests.

\section{Acknowledgments}

The authors thank the colleagues from Taiyuan University of Technology for their assistance during this work. This work was sponsored by the Taiyuan Green Coke Clean Energy Co., Ltd. (China).

\section{References}

[1] W.-H. Chen, M.-R. Lin, T.-S. Leu, and S.-W. Du, "An evaluation of hydrogen production from the perspective of using blast furnace gas and coke oven gas as feedstocks," International Journal of Hydrogen Energy, vol. 36, no. 18, pp. 11727-11737, 2011.

[2] R. Razzaq, C. Li, and S. Zhang, "Coke oven gas: availability, properties, purification, and utilization in China," Fuel, vol. 113, pp. 287-299, 2013.

[3] J. M. Bermúdez, A. Arenillas, R. Luque, and J. A. Menéndez, "An overview of novel technologies to valorise coke oven gas surplus," Fuel Processing Technology, vol. 110, pp. 150-159, 2013.

[4] W. G. Du, S. J. Liu, J. Shangguan, F. Gao, and J. Chen, "Method for producing natural gas by reduction magnetizing hematite with coke-oven gas," P.R.China Patent, CN102311821A.

[5] W.-H. Chen, M.-R. Lin, A. B. Yu, S.-W. Du, and T.-S. Leu, "Hydrogen production from steam reforming of coke oven gas and its utility for indirect reduction of iron oxides in blast furnace," International Journal of Hydrogen Energy, vol. 37, no. 16, pp. 11748-11758, 2012.

[6] J. Lu, S. Liu, J. Shangguan, W. Du, F. Pan, and S. Yang, “The effect of sodium sulphate on the hydrogen reduction process of nickel laterite ore," Minerals Engineering, vol. 49, pp. 154-164, 2013.
[7] P. Pourghahramani and E. Forssberg, "Effects of mechanical activation on the reduction behavior of hematite concentrate," International Journal of Mineral Processing, vol. 82, no. 2, pp. 96$105,2007$.

[8] M. Challenor, P. Gong, D. Lorenser et al., "Iron oxide-induced thermal effects on solid-state upconversion emissions in NaYF4:Yb,Er nanocrystals," ACS Applied Materials and Interfaces, vol. 5, no. 16, pp. 7875-7880, 2013.

[9] H. Fan, K. Xie, J. Shangguan, F. Shen, and C. Li, "Effect of calcium oxide additive on the performance of iron oxide sorbent for high-temperature coal gas desulfurization," Journal of Natural Gas Chemistry, vol. 16, no. 4, pp. 404-408, 2007.

[10] H.-L. Fan, J. Shangguan, L.-T. Liang, C.-H. Li, and J.-Y. Lin, "A comparative study of the effect of clay binders on iron oxide sorbent in the high-temperature removal of hydrogen sulfide," Process Safety and Environmental Protection, vol. 91, no. 3, pp. 235-243, 2013.

[11] N. Jordan, A. Ritter, A. C. Scheinost, S. Weiss, D. Schild, and R. Hübner, "Selenium(IV) uptake by maghemite $\left(\gamma-\mathrm{Fe}_{2} \mathrm{O}_{3}\right)$," Environmental Science and Technology, vol. 48, no. 3, pp. 16651674, 2014.

[12] E. Potapova, I. Carabante, M. Grahn, A. Holmgren, and J. Hedlund, "Studies of collector adsorption on iron oxides by in situ ATR-FTIR spectroscopy," Industrial and Engineering Chemistry Research, vol. 49, no. 4, pp. 1493-1502, 2010.

[13] Z. Yu, C. Li, Y. Fang, J. Huang, and Z. Wang, "Reduction rate enhancements for coal direct chemical looping combustion with an iron oxide oxygen carrier," Energy \& Fuels, vol. 26, no. 4, pp. 2505-2511, 2012.

[14] Z. Yu, C. Li, X. Jing et al., "Effects of $\mathrm{CO}_{2}$ atmosphere and $\mathrm{K}_{2} \mathrm{CO}_{3}$ addition on the reduction reactivity, oxygen transport capacity, and sintering of $\mathrm{CuO}$ and $\mathrm{Fe}_{2} \mathrm{O}_{3}$ oxygen carriers in coal direct chemical looping combustion," Energy and Fuels, vol. 27, no. 5, pp. 2703-2711, 2013.

[15] Z. Yu, C. Li, X. Jing et al., "Catalytic chemical looping combustion of carbon with an iron-based oxygen carrier modified by $\mathrm{K}_{2} \mathrm{CO}_{3}$ : catalytic mechanism and multicycle tests," Fuel Processing Technology, vol. 135, pp. 119-124, 2015.

[16] C. Li, H. Sun, J. Bai, and L. Li, "Innovative methodology for comprehensive utilization of iron ore tailings: part 1 . The recovery of iron from iron ore tailings using magnetic separation after magnetizing roasting," Journal of Hazardous Materials, vol. 174, pp. 71-77, 2010.

[17] C. Li, H. Sun, J. Bai, and L. Li, "Innovative methodology for comprehensive utilization of iron ore tailings: part 2: the residues after iron recovery from iron ore tailings to prepare cementitious material," Journal of Hazardous Materials, vol. 174, pp. 78-83, 2010.

[18] W. K. Jozwiak, E. Kaczmarek, T. P. Maniecki, W. Ignaczak, and W. Maniukiewicz, "Reduction behavior of iron oxides in hydrogen and carbon monoxide atmospheres," Applied Catalysis A: General, vol. 326, no. 1, pp. 17-27, 2007.

[19] H. L. Gilles and C. W. Clump, "Reduction of iron ore with hydrogen in a direct current plasma jet," Industrial and Engineering Chemistry, vol. 9, no. 2, pp. 194-207, 1970.

[20] A. Mcgeorge Jr., A. H. Hixson, and K. A. Krieger, "Low temperature gaseous reduction of iron ore in the presence of alkali," I and E C Process Design and Development, vol. 1, no. 3, pp. 217225, 1962.

[21] J. Zieliński, I. Zglinicka, L. Znak, and Z. Kaszkur, "Reduction of $\mathrm{Fe}_{2} \mathrm{O}_{3}$ with hydrogen," Applied Catalysis A: General, vol. 381, no. 1-2, pp. 191-196, 2010. 
[22] K.-S. Kang, C.-H. Kim, K.-K. Bae et al., "Reduction and oxidation properties of $\mathrm{Fe}_{2} \mathrm{O}_{3} / \mathrm{ZrO}_{2}$ oxygen carrier for hydrogen production," Chemical Engineering Research and Design, vol. 92, no. 11, pp. 2584-2597, 2014.

[23] N. J. Welham, "Activation of the carbothermic reduction of manganese ore," International Journal of Mineral Processing, vol. 67, no. 1-4, pp. 187-198, 2002.

[24] A. Pineau, N. Kanari, and I. Gaballah, "Kinetics of reduction of iron oxides by H2. Part II. Low temperature reduction of magnetite," Thermochimica Acta, vol. 456, no. 2, pp. 75-88, 2007.

[25] A. Pineau, N. Kanari, and I. Gaballah, "Kinetics of reduction of iron oxides by H2. Part I: low temperature reduction of hematite," Thermochimica Acta, vol. 447, no. 1, pp. 89-100, 2006.

[26] J. P. Martins and F. Margarido, "The cracking shrinking model for solid-fluid reactions," Materials Chemistry and Physics, vol. 44, no. 2, pp. 156-169, 1996.

[27] X. Liu, F. Song, and Z. Wen, "A novel dimensionless form of unreacted shrinking core model for solid conversion during chemical looping combustion," Fuel, vol. 129, pp. 231-237, 2014.

[28] D. da Rocha, E. Paetzold, and N. Kanswohl, "The shrinking core model applied on anaerobic digestion," Chemical Engineering and Processing: Process Intensification, vol. 70, pp. 294-300, 2013.

[29] Y. Yu and C. Qi, "Magnetizing roasting mechanism and effective ore dressing process for oolitic hematite ore," Journal Wuhan University of Technology, Materials Science Edition, vol. 26, no. 2, pp. 176-181, 2011.

[30] W. V. Schulmeyer and H. M. Ortner, "Mechanisms of the hydrogen reduction of molybdenum oxides," International Journal of Refractory Metals and Hard Materials, vol. 20, no. 4, pp. 261-269, 2002.

[31] K. Higuchi and R. H. Heerema, "Influence of sintering conditions on the reduction behaviour of pure hematite compacts," Minerals Engineering, vol. 16, no. 5, pp. 463-477, 2003.

[32] H. Veeramani, D. Aruguete, N. Monsegue et al., "Low-temperature green synthesis of multivalent manganese oxide nanowires," ACS Sustainable Chemistry \& Engineering, vol. 1, no. 9, pp. 1070-1074, 2013. 

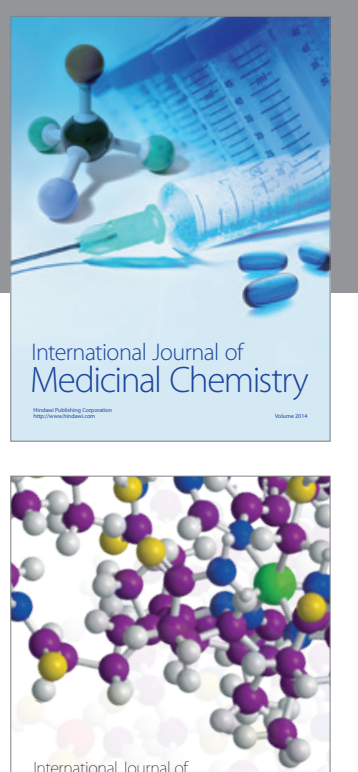

Carbohydrate Chemistry

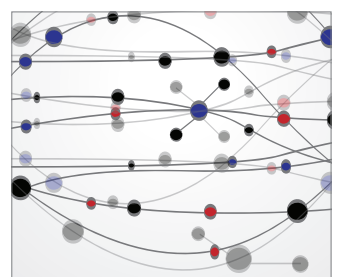

The Scientific World Journal
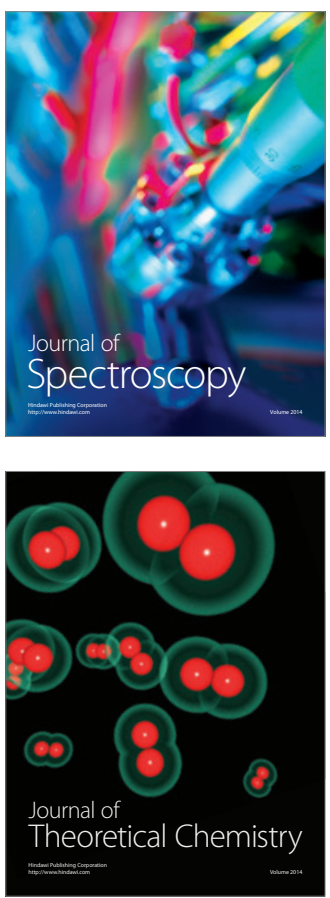
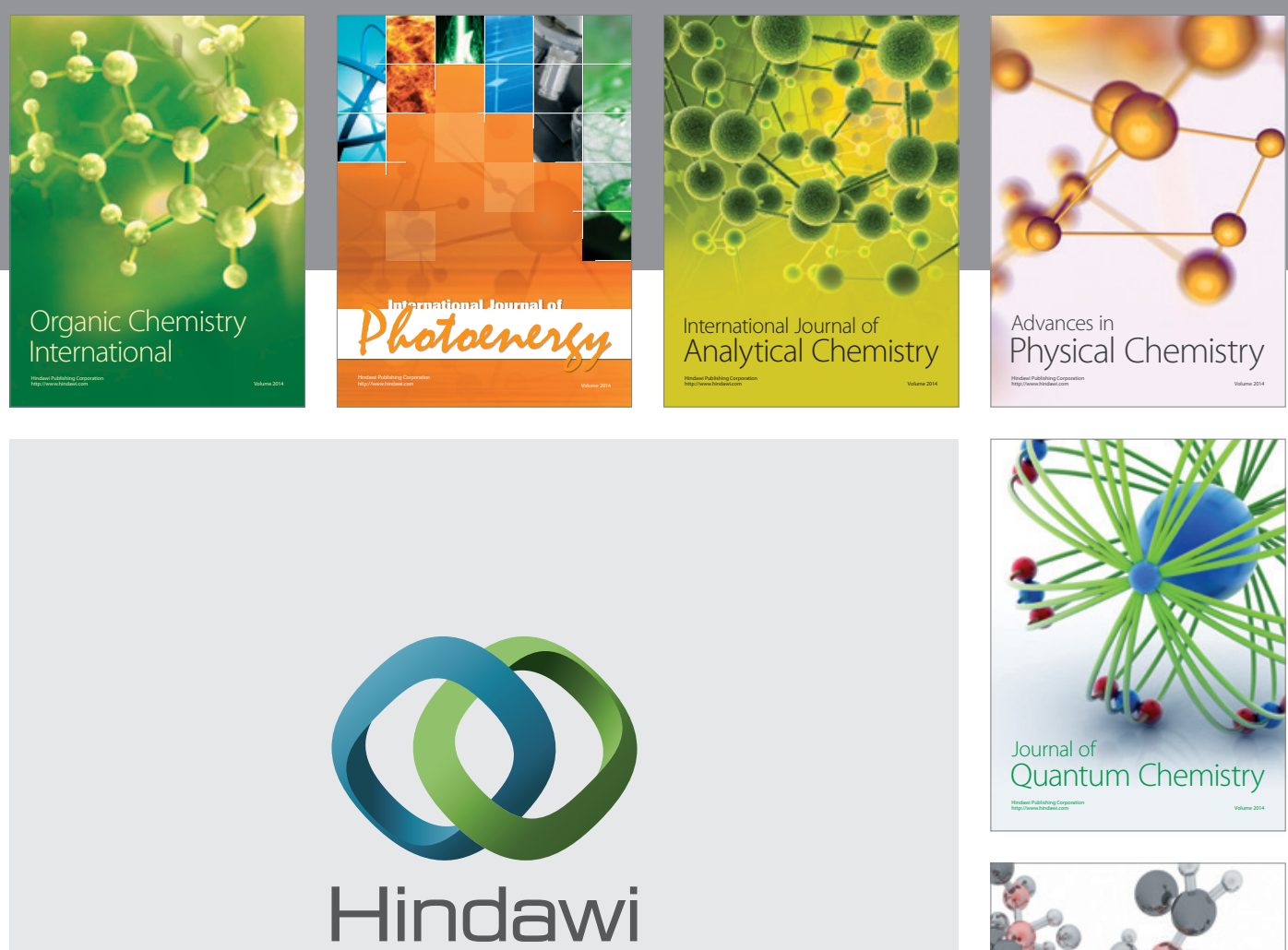

Submit your manuscripts at

https://www.hindawi.com

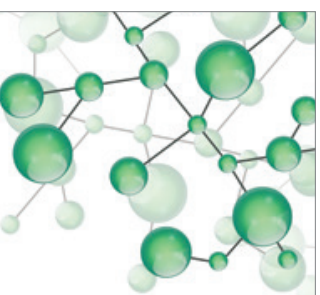

International Journal of

Inorganic Chemistry
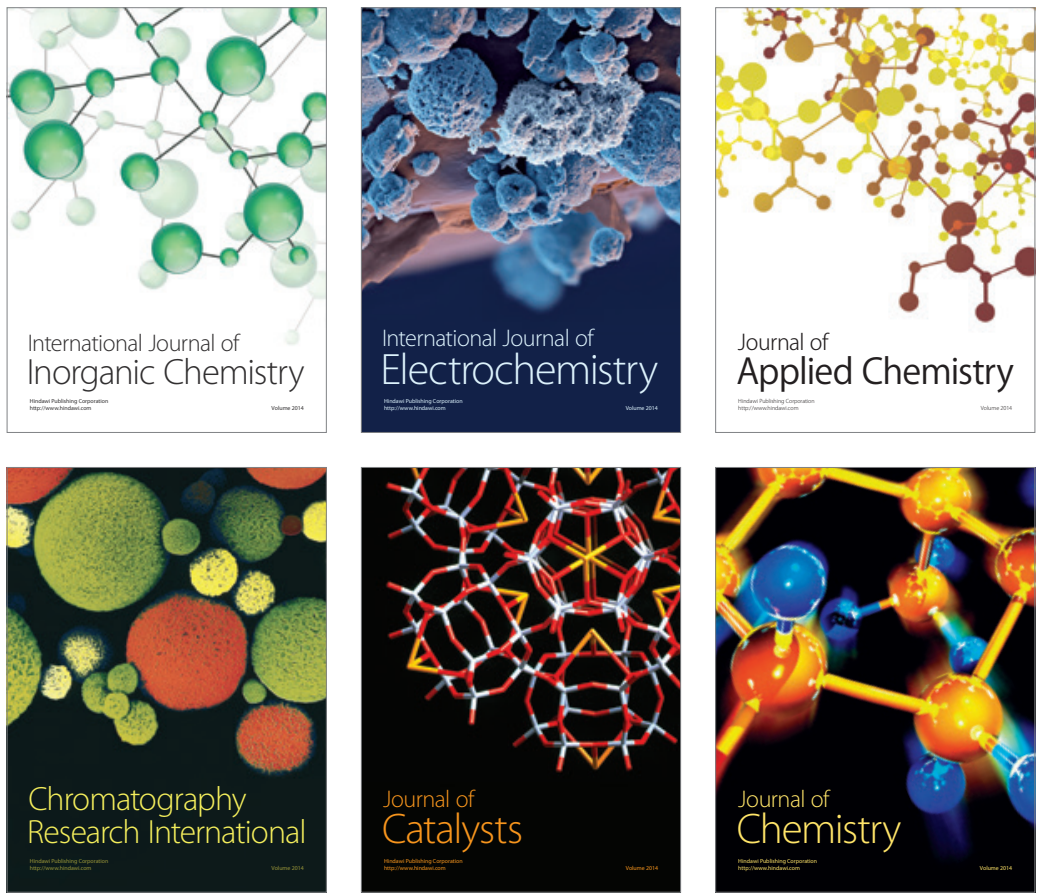

Journal of

Applied Chemistry
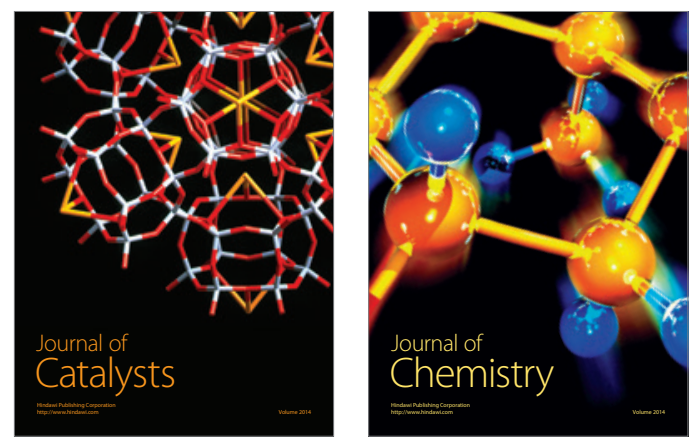
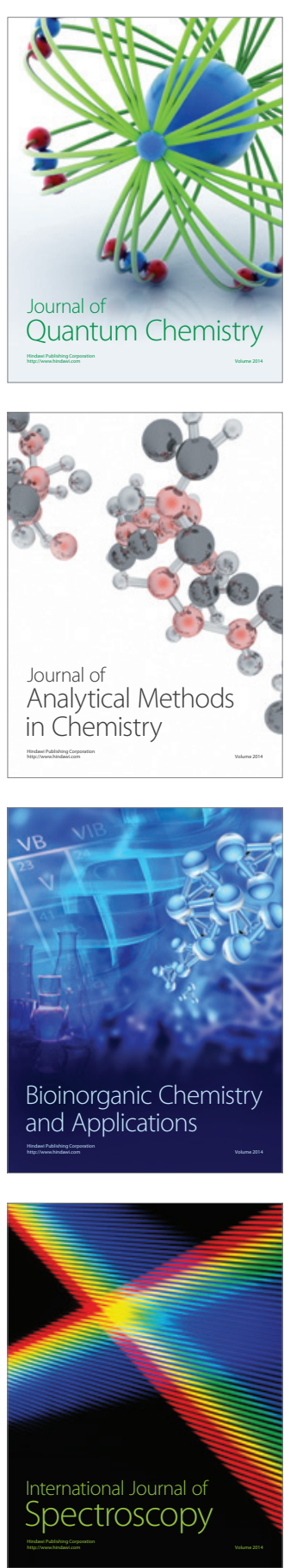